\title{
Belajar dari Kemenangan Jepang pada Perang Tsushima: Pembangunan Kekuatan Militer Angkatan Laut Melalui Industri Strategis
}

\author{
Dede Rusdiana*, Amarulla Octavian, Yusuf Ali, Suryono Thamrin, Aris Sarjito
}

\author{
Program Studi Doktor Ilmu Pertahanan, Universitas Pertahanan, \\ Kawasan IPSC Sentul, Sukahati, Bogor, Jawa Barat - Indonesia
}

*Alamat korespondensi: dede.rusdiana@idu.ac.id DOI: https://doi.org/10.14710/jscl.v6i1.37678

Diterima/Received: 7 April 2020; Direvisi/ Revised: 23 Juli 2021; Disetujui/Accepted: 27 Agustus 2021

\begin{abstract}
The various wars that have been passed have had implications for the development of Japanese combat conditions. One of the wars that sparked the rise of Japanese combat technology was the Tsushima War of 1905, marked by the use of new weaponry such as torpedoes and telegraphs. Japan's victory in the Tsushima War has proven that Japan has advanced weapons technology and has proven to be able to compete with Russia. This study provides a very important lesson and can be a reflection for Indonesia in the development of a naval military force. By using historical methods and defense economic theory approaches, this study discusses efforts to increase the strength of the main weapon system of the Japanese special navy. The results of the study show that the efforts made by Japan put a lot of emphasis on the strategy of developing the defense industry. The rise of the defense industry has become an integral part of military power building. In that context, Japan does not only involve the military, but also develops human resource capacity and increases research in the field of technology. The existence of good cooperation between the government, industry players, and academia is also the main pillar in the effort to build a naval military force.
\end{abstract}

Keywords: Defense Industry; Military Strength; Tsushima War.

\begin{abstract}
Abstrak
Berbagai perang yang dilalui telah berimplikasi pada perkembangan terkonogi pertempuran Jepang. Salah satu perang yang memantik kebangkitan teknologi pertempuran Jepang adalah Perang Tsushima 1905, ditandai dengan penggunaan persenjataan baru seperti torpedo dan telegraf. Kemenangan Jepang pada Perang Tsushima telah membuktikan bahwa Jepang memiliki teknologi persenjataan yang maju dan terbukti dapat bersaing dengan Rusia. Kajian ini memberikan pembelajaran yang sangat penting dan dapat menjadi sebuah refleksi bagi Indonesia dalam pembangunan kekuatan militer angkatan laut. Dengan menggunakan metode sejarah dan pendekatan teori ekonomi pertahanan, kajian ini membahas upaya-upaya peningkatan kekuatan sistem persenjataan utama angkatan laut khusus Jepang. Hasil penelitian menunjukkan bahwa upaya yang dilakukan Jepang sangat mengedepankan strategi pengembangan industri pertahanan. Kebangkitan industri pertahanan telah menjadi bagian integral dari pembangunan kekuatan militer. Dalam konteks itu, Jepang bukan hanya melibatkan kalangan militer saja, melainkan juga melakukan pengembangan kapasitas sumber daya manusia dan peningkatan riset di bidang teknologi. Adanya kerja sama yang baik antara pemerintah, pelaku industri, dan akademisi juga menjadi pilar utama dalam upaya pembangunan kekuatan militer angkatan laut.
\end{abstract}

Kata Kunci: Industri Pertahanan; Kekuatan Militer; Perang Tsushima.

\section{Pendahuluan}

Kajian mengenai industri pertahanan telah dilakukan oleh Tuwanto (2015). Menurutnya, industri pertahanan suatu negara dewasa ini memiliki kaitan erat dengan perkembangan ekonomi. Industri pertahanan yang dimaksud adalah industri yang berorientasi pada produksi alat utama sistem senjata (alutsista), baik senjata ringan maupun berat, kendaraan tempur, serta kendaraan pendukung kegiatan pertahanan. Industri itu juga meliputi pemeliharaan dan perbaikan alutsista. Kendati demikian, industri pertahanan sering kali kurang mendapatkan perhatian terutama di negara-negara berkembang karena harus berkutat dengan isu yang dianggap 
lebih krusial yaitu pendidikan, kesehatan, kemiskinan, dan pemenuhan kebutuhan dasar sehari-hari warga negara. Persoalan itu menjadikan industri pertahanan kurang mendapatkan perhatian, padahal pengembangan industri pertahanan memiliki peranan dalam percaturan perekonomian global. Prokontra seputar industri pertahanan juga terjadi di Indonesia. Tuwanto menyatakan bahwa di Indonesia, posisi industri pertahanan sering kali tersudut oleh berbagai kepentingan. Satu hal yang luput dari perhatian para pemangku kebijakan adalah bahwa industri pertahanan semestinya bukan hanya mementingkan aspek keuntungan saja, melainkan juga berkaitan dengan aspek keamanan dan kedaulatan negara. Berdasar pada permasalahan tersebut, kajian ini adalah sebuah refleksi dengan memetik pelajaran dari industri pertahanan Jepang yang kemudian membawa negara tersebut pada kemenangan perang, sehingga semakin diakui eksistensinya dalam kancah global.

Industri pertahanan Jepang terus berkembang sebagai bentuk antisipasi terhadap berbagai bentuk ancaman. Perkembangan pembangunan industri pertahanan Jepang salah satunya dapat dipelajari dari Perang Tsushima yang terjadi pada 1905. Perang Tsushima adalah perang laut yang melibatkan Jepang dan Rusia. Pada akhir abad ke-19, kerajaan Asia Timur, termasuk Cina, Korea dan Siam, mengadopsi ilmu pengetahuan dan teknologi baru yang ditawarkan oleh negara-negara Eropa (Grove, 1998). Penguasa Jepang ,Kaisar Meiji, menyadari bahwa apabila bangsanya tidak mengarah ke peradaban modern, maka negaranya akan menjadi koloni kekuatan Barat. Sejak berkuasa pada 1867 hingga 1894, Meiji mempersatukan Jepang dan menciptakan negara industri untuk menggantikan sistem feudal 1850-an (Ikegami, 1995).

Restorasi Meiji yang mengakselerasi industrialisasi di Jepang merupakan modal untuk kebangkitan Jepang sebagai kekuatan militer pada 1905 di bawah slogan 'Negara Makmur, Militer Kuat'. Perubahan ekonomi dan sosial berjalan sesuai dengan transformasi politik selama periode Restorasi Meiji (Gordon, 2003). Meskipun sektor ekonomi masih bergantung pada pertanian, industrialisasi menjadi tujuan utama pemerintah Jepang dalam mengarahkan pengembangan industri strategis, transportasi, dan komunikasi. Pada periode itu, juga dibangun jalur kereta api pertama pada 1872. Hampir dua dekade setelahnya, Jepang telah memiliki rel kereta api sepanjang $1.400 \mathrm{mil}(2.250 \mathrm{~km})$. Jaringan telegrafpun dibangun untuk menghubungkan semua kota besar pada 1880. Dua tahun berikutnya, perusahaan swasta terus didorong untuk berkembang dengan bantuan keuangan dari pemerintah dan institusi sistem perbankan bergaya Eropa (Yamamura, 1977).

Pada 1902, Jepang dan Inggris Raya merundingkan aliansi Inggris-Jepang. Perundingan tersebut didasari atas pandangan Inggris terhadap Rusia. Dalam konteks itu, Rusia dianggap sebagai ancaman strategis. Oleh sebab itu, Inggris menginginkan Jepang menjadi penyeimbang. Ditambah lagi, Jepang telah membubarkan Semenanjung Liaodong karena tidak memiliki kekuatan untuk melawan aliansi Rusia-Jerman sejak 1895. Pada 13 Januari 1904, pemerintah Jepang mengirimkan tawaran terbaik dan terakhir kepada Rusia, yaitu menyerahkan Manchuria. Sementara itu, Korea berada dalam pengaruh Jepang. Namun demikian, Pemerintah Rusia mengabaikan proposal tersebut sehingga pada 4 Febuari Jepang memutuskan hubungan diplomatik dengan Rusia. Pada 8 Februari, Angkatan Laut Kekaisaran Jepang menyerang Armada Pasifik Rusia di Port Arthur. Penyerangan itu telah menjadi perang besar pertama di awal abad ke-19 (Till, 2006).

Adapun kemenangan Jepang pada Perang Tsushima tidak lepas dari pengembangan teknologi peralatan tempur. Pada 1897 senapan standar pasukan infanteri Jepang adalah Tipe 30. Senjata itu kemudian didesain ulang oleh Mayor Kijiro Nambu dan Baron Arisaka Nariakira menjadi Arisaka Tipe 38. Nambu sendiri dikenal sebagai perancang pistol yang mirip dengan Luger Jerman. Sebagaimana diketahui bahwa Jerman merupakan negara penting bagi Jepang. Jerman dan Jepang telah menjalin kerjasama di bidang teknologi sebelum Perang Dunia II. Jepang juga belajar dari Jerman dalam membangun kekuatan militer darat, serta dari Inggris dan Prancis untuk angkatan laut. Hal itu ditandai dengan perusahaan Mitsubishi Nagasaki Shipyard yang memproduksi kapal-kapal tempur berdaya gerak cepat sejak 1870 
atau dua tahun setelah Restorasi Meiji. Iwasaki Yataro (1835-1885) pada mulanya mendirikannya sebagai perusahaan pengiriman, namun rentang waktu 1940-an, Mitsubishi berhasil memproduksi pesawat terbang bernama Mitsubishi A6M Zero yang diketahui sangat menakutkan pada awal Perang Dunia II (Elliot \& Milne, 2019).

Sejarah industri pertahanan khususnya kekuatan laut Jepang telah menjadi tolak ukur kebangkitan pertahanan asia-pasifik. Adapun tantangan pembangunan industri pertahanan adalah mempertemukan berbagai peluang untuk memperkuat jalinan. Dalam konteks ini, Jepang telah berhasil menggabungkan berbagai kekuatan mulai dari lembaga riset, pelaku usaha, hingga masyarakat. Mereka bergabung demi kemajuan negara. Mengenai pengintegrasian berbagai kekuatan itu, Perang Tsushima telah menjadi bagian pembelajaran penting bagi Indonesia. Pada kajian ini dibahas mengenai berbagai upaya yang dilakukan oleh Jepang dalam membangun kekuatan yang tentunya dapat menjadi refleksi dan pembelajaran bagi Indonesia. Perang Tsushima merupakan salah satu peristiwa besar dalam Perang Rusia-Jepang.

Kajian mengenai kesuksesan Jepang dalam Perang Rusia-Jepang telah dilakukan oleh Koda (2005). Koda menyatakan bahwa Jepang telah bergabung dengan komunitas internasional sejak pertengahan abad ke-19. Periode itu disebut dengan "zaman imperialisme" yang ditandai dengan dominasi negara-negara Barat. Dengan keinginan belajar yang kuat serta berbagai upaya peningkatan kapasitas sumber daya manusia, Jepang akhirnya berhasil memperluas kontak dengan negara-negara asing. Para pemimpin Jepang, meskipun tidak memiliki banyak pengalaman, nyatanya telah mampu menyelesaikan persoalan-persoalan diplomatik dengan langkah yang menguntungkan Jepang sendiri. Keberhasilan dalam menangani persoalan diplomatik telah mengangkat derajat Jepang sehingga diakui secara internasional.

Lebih jauh Koda membahas tentang ketegasan, keterampilan, dan kemampuan berkoordinasi yang dimiliki oleh para pemimpin Jepang sehingga mampu menyusun strategi dalam rangka beradaptasi di "zaman imperialisme". Para pemimpin Jepang juga menunjukkan keseimbangan dalam memperkirakan situasi. Hal itu terutama ditunjukkan sepanjan episode Perang Rusia-Jepang (seperti Perang Tiongkok-Jepang 1894-1895). Diketahui perang tersebut telah mengubah masa depan bangsa Jepang. Koda telah membahas secara detail strategi, kebijakan, serta kepemimpinan Jepang selama Perang RusiaJepang yang ia klaim sebagai penentu keberhasilan Jepang. Namun demikian, Koda tidak membahas secara eksplisit strategi pengembangan kekuatan angkatan laut dalam kaitannya dengan pengembangan teknologi perang, khususnya yang digunakan pada Perang Tsushima (Koda, 2005).

Setelah berhasil meraih kemenangan atas Tiongkok pada 1895 dan disusul dengan kemengangan pada Perang Tsushima, Jepang semakin diperhitungkan di dunia internasional. Dengan demikian, pemberdayaan industri strategis Jepang menjadi studi yang menarik mengingat negara-negara yang berperang dengan Jepang adalah negara-negara yang dikenal terlebih dahulu besar (Bitzinger \& Boutin, 2009).

\section{Metode}

Oleh karena berfokus pada pembangunan kekuatan militer Jepang guna menghadapi Perang Tsushima, kajian ini menggunakan metode sejarah. Dalam kajian sejarah ada empat tahapan heuristik, kritik, interpretasi, dan historiografi. Namun demikian, penggunaan studi literatur masih tetap relevan untuk digunakan. Studi ini berdasar pada pemikirin kualitatif sejarah yang bermaksud untuk memahami upaya Jepang dalam memberdayakan industri strategisnya guna membangun kekuatan militer yang tangguh (Moleong, 2010).

\section{Latar Belakang Perang Tsushima}

Masyarakat Jepang pada mulanya sebagian besar bekerja di bidang pertanian. Seiring dengan perkembangan zaman, dengan adanya perubahan peraturan perundang-undangan seperti reformasi agraria dan perburuhan, mereka beralih pada sektor industri. Dari sinilah kemudian sistem Zaibatsu (industri dan bisnis keuangan) berkembang dengan pesat. Terpusatnya berbagai kegiatan ekonomi terhadap beberapa kelompok masyarakat menjadi trend perekonomian yang 
berkembang di Jepang. Di bawah kepemimpinan Perdana Menteri Ikeda, Jepang merumuskan strategi yang disebut dengan Rencana "Pelipat gandaan Penghasilan” (incoming-doubling plan). Strategi ini direspons dengan pembentukkan Badan Perencanaan Ekonomi. Jepang mulai melakukan perubahan dan proses mempercepat pertumbuhan menyeluruh pada dekade 1870-an. Proses sejarah industri yang dibangun secara sosial antara masyarakat, pengusaha, dan pemerintah dapat menjadi pelajaran yang baik bagi dasar peletakkan pemerintah Jepang dalam mengatur perekonomiannya (Ike, 1948).

Pada 1894, Jepang memiliki kepercayaan yang cukup pada bidang teknologi dan militer untuk melawan Kekaisaran Qing dari Tiongkok. Dalam waktu kurang dari sembilan bulan, Jepang berhasil mengalahkan China (Holmes, 2014). Jepang merebut Korea dari pengikut Cina dan mendapatkan Taiwan, tepatnya Penghu (Kepulauan Pescadores), serta Semenanjung Liaodong sebagai rampasan perang. Saat Jepang mengalahkan Cina pada Perang Tiongkok Pertama (1894-1895), Rusia mulai bergerak ke selatan Siberia, mencari pelabuhan air hangat yang sangat bagus di ujung selatan Semenanjung Liaodong. Hal inilah yang memicu konflik kepentingan antara Jepang dan Rusia (Ivanov \& Karachtchouk, 2004).

Pada 6 Februari 1904, Jepang memutuskan hubungan diplomatik dengan Rusia. Pada hari yang sama, armada gabungan Jepang di bawah pimpinan Laksamana Togo Heihachiro berlayar ke Pantai Korea. Mereka berlayar melewati Pelabuhan Chemulpo (di sekitar Seoul). Armada perang Jepang dibagi menjadi dua. Armada yang lebih kecil dipimpin oleh Laksamana Muda Ury Sotokichi. Dalam misi penyerangan ini, armada perang Jepang merusak kapal-kapal milik Rusia yang berlabuh di Port Arthur. Meskipun tidak banyak kapal yang berhasil dirusak, namun penyerangan ini telah menjadi genderang perang karena keesokan harinya, pasukan Jepang berhasil menguasai Korea untuk kali pertama dan memaksa Angkatan Laut Rusia menyingkir dari Pelabuhan Chemulpo. Pada awalnya, Angkatan Laut Rusia menyingkir seperti tidak terjadi apa-apa. Namun kemudian, pasukan Rusia kembali dan merusak kapal-kapal Jepang. Keesokan harinya, Jepang menyatakan perang secara resmi terhadap Rusia yang sekaligus menandai dimulainya perang selama 19 bulan. Salah satu peristiwa besar dalam perang tersebut adalah Perang Tsushima (Kowner, 2007).

\section{Faktor Kemenangan Jepang pada Perang Tsushima 1905}

\section{Penggunaan Kapal Bersenjata Canggih}

Pertempuran Tsushima terjadi pada 27-28 Mei 1905 (14-15 Mei dalam kalender Julian yang saat itu digunakan di Rusia) di Selat Tsushima yang terletak di antara Korea dan Jepang selatan sebagaimana terlihat pada Gambar 1. Dalam pertempuran ini, armada Jepang di bawah Laksamana Tōgō Heihachirō menghancurkan dua pertiga dari armada Rusia, di bawah Laksamana Zinovy Rozhestvensky, yang telah melakukan perjalanan lebih dari 18.000 mil laut $(33.000 \mathrm{~km})$ untuk mencapai Timur Jauh. Sementara itu, di London pada 1906, Sir George Sydenham Clarke menyatakan bahwa Pertempuran Tsushima merupakan pertempuran laut terbesar dan paling penting sejak Trafalgar.

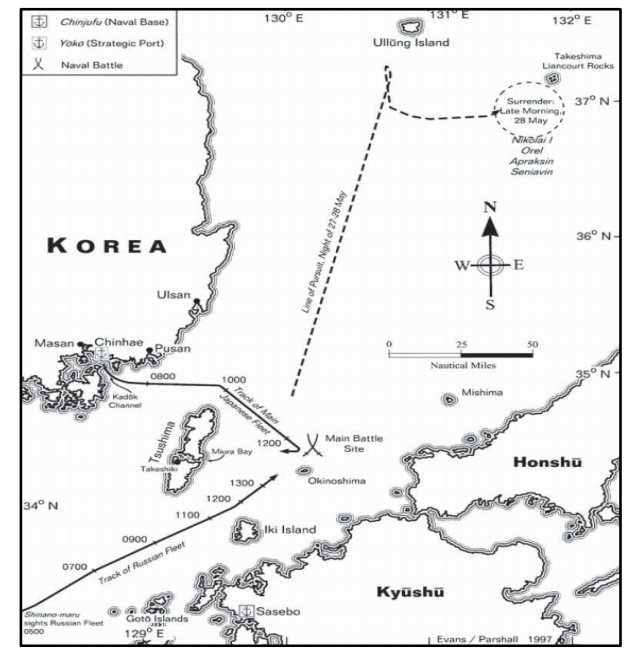

Gambar 1. Peta Posisi Perang Tsushima Sumber: Stille, 2016.

Jepang mengerahkan armada laut yang cukup besar pada Perang Tsushima. Hal itu membuktikan bahwa perang tersebut telah pula melahirkan senjata-senjata terbaik yang mampu memberikan kemenangan pada Jepang. Kapalkapal perang utama yang digunakan oleh Jepang yaitu Kapal Fuji, Yashima, Shikishima, Hatsuse, Asahi dan Mikasa. Kapal-kapal tersebut sebagian besar dibuat oleh Inggris melalui perusahaan 
Thames Iron Work, Armstrong Withworth, dan J. Brown. Secara umum, kapal-kapal tersebut dipersenjatai dengan senjata $12 \mathrm{in} / 40,6 \mathrm{in} / 40$, 3in, $47 \mathrm{~mm}$ dan 18 in torpedo. Selanjutnya, kapal perang kelas dua yang digunakan adalah Kapal Chin Yen buatan Jerman yang merupakan rampasan dari China. Kapal ini dipersenjatai dengan senjata $12 \mathrm{in} / 20,6 \mathrm{in} / 40,57 \mathrm{~mm}, 47 \mathrm{~mm}$ dan 14 in torpedo. Lalu, kapal perang kelas tiga yang diberangkatkan yaitu Fuso yang dipersenjatai meriam 6in/50, $4,7 \mathrm{in} / 40,57 \mathrm{~mm}, 47 \mathrm{~mm}$ dan 18 in torpedo (Stille, 2016).

Selain kapal utama yang dilengkapi senjatasenjata canggih, Jepang juga menggunakan kapal jelajah cepat yaitu Asama, Tokiwa, Yakumo, Adzuma, Idzumo, Iwate, Kasuga dan Nisin. Kasuga dan Nisin merupakan kapal yang dibeli dari Italia. Kapal-kapal tersebut memiliki kecepatan di atas 20 knot. Tidak hanya itu, Jepang juga mengerahkan kapal-kapal pelindung antara lain Naniwa, Takachiho, Itsukhushima, Matshushima, Hashidate, dan Chiyoda. Kapal-kapal perang yang diproduksi sendiri di galangan kapal Yokosuka Navy Yard adalah kapal Akitshushima, Suma, Otowa, dan Akashi. Jepang juga membeli kapal perang dari Amerika yaitu kapal Kasagi dan Chitose. Kemudian, Jepang juga menggunakan kapal jenis destroyer yaitu kapal Akebono, Shiranui, dan Hayabusa seperti terlihat pada Gambar 2.

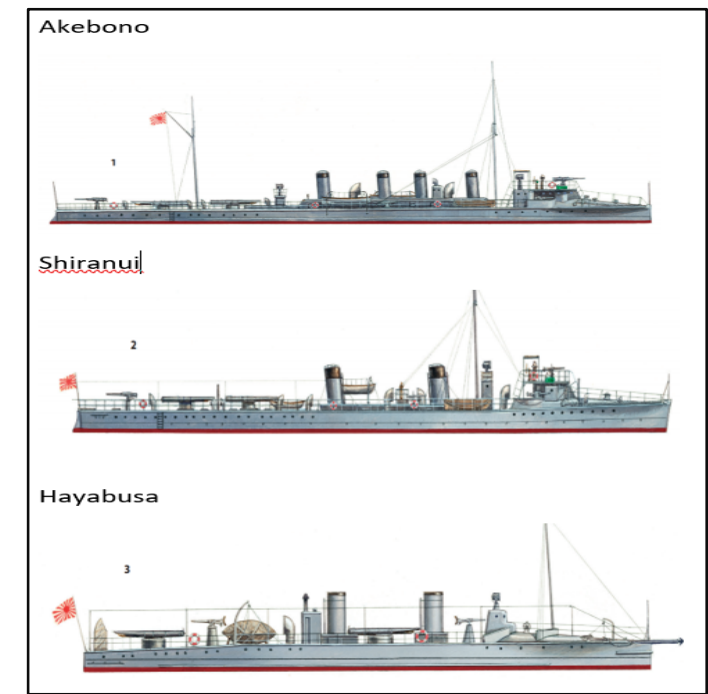

Gambar 2. Sketsa kapal-kapal destroyerJepang para Perang Tsushima.

Sumber: Stille, 2016.

\section{Peningkatan Kapasitas Sumber Daya Manusia}

Penggunaan kapal bersenjata canggih tentu harus didukung oleh sumber daya manusia yang dapat mengoperasikan. Beberapa perwira Jepang yang belajar di French Jeune Ecole mendapat pengetahuan tentang efisiensi dari torpedo untuk melawan kapal-kapal perang yang besar. Pada 1870, Jepang mengirimkan perwiranya untuk belajar self-propelled torpedo di Inggris. Sekembalinya dari Inggris mereka merintis pembentukan Pusat Pelatihan Torpedo di Yokosuka pada 1886. Adapun kapal-kapal torpedo yang dijadikan media pembelajaran dibeli dari Prancis, Jerman, dan Inggris. Kapal-kapal torpedo tersebut dibagi menjadi tiga kelas. Kelas pertama adalah kapal dengan bobot di atas 120 ton. Kelas dua adalah kapal dengan bobot 70-120 ton. Sementara itu, kelas 3 adalah kapal dengan bobot di bawah 70 ton (Lone, 1994).

Kapal torpedo yang termasuk kelas satu antara lain Kotaka, Shirataka, Hayabusa, Kasasgi, Manazuru, Chidori, Aotaka, Kari, Hato, Hibari, Kiji, Tsubame, Hashitaka, Sagi, Kamone, Otori dan Uzura. Kapal-kapal tersebut memiliki kecepatan yang cukup tinggi antara 19,5-28,5 knot dan dipersenjatai dengan Meriam, 37mm, 47mm, 57 $\mathrm{mm}$ dan torpedo 17,7 in. Kapal torpedo yang termasuk kelas dua antara lain kapal-kapal bernomor lambung 21-25, 29-49, dan 60-75. Kapal-kapal tersebut memiliki kecepatan 19-26 knot dan dipersenjatai dengan Meriam $47 \mathrm{~mm}$, $57 \mathrm{~mm}$, dan torpedo 14 in atau 15 in. Selanjutnya kapal kelas 3 yaitu kapal bernomor lambung 50-20, 26 dan 50-59. Kapal-kapal tersebut memiliki kecepatan berkisar 20 knot dan dipersenjatai dengan Meriam $47 \mathrm{~mm}$ dan torpedo 14,2 in.

Armada Jepang telah terbukti mampu mendeteksi kedatangan Armada Pasifik kedua Rusia dengan teknologi telegrafi nirkabel. Teknologi ini ditemukan oleh Uglielmo Marconi (25 April 1874-20 Juli 1937). Pengembangan telegraf nirkabel jarak jauh pertama sukses pada 1894 dan penyiaran sinyal radio transatlantik pertama pada 1901 (Lardas, 1980).

Sementara itu, radiotelegrafi dan transmitter dikembangkan untuk komunikasi kapal ke pantai dan kapal ke kapal. Bentuk radiotelegrafi memungkinkan komunikasi sederhana antara dua titik. Penggunaan jaringan nirkabel meningkat 
setelah terbukti efektif melancarkan komunikasi untuk pekerjaan penyelamatan di laut. Tidak lama kemudian, sejumlah kapal laut bahkan memasang peralatan nirkabel. Pada 1899, Angkatan Darat Amerika Serikat menjalin komunikasi nirkabel dengan kapal suar di lepas pantai Fire Island, New York. Dua tahun kemudian, Angkatan Laut mengadopsi sistem nirkabel. Teknologi tersebut terus bertransformasi menjadi radio modern seperti saat ini.

\section{Pemberdayaan Industri Strategis dari Pengalaman perang Tsushima}

Yukiko Fukasaku dalam penelitiannya menyebutkan bahwa Jepang mengembangkan industri dalam negeri sambil membeli teknologi dari luar negeri. Di dalam proses pengembangan industri tersebut, para pimpinan Jepang melibatkan perusahaan, akademisi, lembaga keuangan, yang terintegrasi dalam kebijakan pemerintah. Dalam konteks itu, Jepang mengadopsi model Arrow (1962), yaitu learning by doing yang menyatakan bahwa produktifitas dapat meningkat tanpa menambah investasi baru karena proses pembelajaran merupakan akumulasi dari pengalaman dalam berproduksi. Lall (1980) menggambarkan klasifikasi tiga tahap (dasar, menengah, dan lanjutan) melalui adaptasi sampai dengan tahap inovasi, sehingga mampu menawarkan proses baru atau produk baru. Konsep learning by doing menunjukkan pentingnya kegiatan seperti belajar mengoperasikan, mengubah, belajar melalui pelatihan dengan metode praktik. Rosenberg \& Nathan (1982) menunjukkan pentingnya learning by doing. Dalam hal itu, produktivitas yang meningkatkan perubahan teknologi dapat disebabkan oleh informasi umpan balik dari pengguna di industri teknologi tinggi seperti pesawat terbang. Dore (1984) membedakan Independent Technology Learning Capacity sebagai kemampuan untuk mengasimilasi teknologi asing dengan Independent Technology Creation Capacityyang berarti kemampuan untuk beradaptasi dan berubah, untuk memperbaharui kinerja teknologi yang sebelumnya.

Pembelajaran yang dimaksud tersebut dapat terus ditingkatkan melalui pendidikan dan penelitian. Jepang membentuk Akademi Angkatan Laut pada 1869 di Tokyo. Selanjutnya, Jepang terus mengembangkan Lembaga Riset dan Teknologi secara komprehensif sebelum 1900, yang meliputi Hokkaido Development Research Institute (1871), Naimusho, Naito Shinjuku Laboratory (1872), Kobusho Telegraph Departement Electric \& Glass Laboratory (1875), Yokohama Raw Silk Laboratory (1895), dan Epidemics Research Institute (1899).

Beberapa syarat yang memungkinkan industri pertahanan dapat dibangun antara lain potensi sumber daya manusia, sumber daya alam, dan sumber daya buatan yang kuat. Adapun kemampuan penguasaan ilmu pengetahuan dan teknologi merupakan hal yang mutlak dalam menopang keberhasilan industri pertahanan. Tidak lupa, Kekuatan anggaran yang besar untuk pembiayaan industri pertahanan merupakan kebutuhan wajib. Pada akhirnya, asimilasi teknologi yang berhasil juga bergantung pada upaya di tingkat perusahaan dalam Riset and Development, serta teknik produksi (Pavitt, 1985).

Dalam hal pengembangan sumber daya manusia, Jepang telah mengirimkan para insinyur dan mekanik untuk belajar berbagai disiplin ilmu di beberapa universitas teknik. Sebagai contoh adalah Suzuki dan Motora yang dikirim ke Yawata steel Mill dan Tokyo Imperial University untuk belajar Analisa kimia baja; Kuno dan Mase dikirim untuk belajar mesin diesel di kampus tersebut; Ito $\mathrm{K}$ mempelajari teknologi kapal selam Prancis; Horikawa T untuk belajar teknik elektro di Kyushu Imperial University; Murata, Yamaguchi, Matsuo dan Yamazaki dikirim untuk belajar teknik mesin di Universitas Kyushu; Jimbo dan Torisu mempelajari teknologi perkapalan; serta Aoyama yang mempelajari sistem propulsi kapal di Tokyo Imperial University.

Definisi industri pertahanan adalah proses produksi serta pengembangan berbagai barang/peralatan yang berkaitan dengan aspek pertahanan, khususnya militer, seperti alutsista (roket, tank, helikopter, pesawat terbang, kapal perang, dan kapal selam). Pembangunan industri pertahanan bertujuan untuk mencukupi kebutuhan pertahanan negara sehingga tidak bergantung pada pasokan dari negara lain. Ditambah lagi apabila negara yang bersangkutan 
terkena sanksi internasional, berupa embargo militer setidaknya masih memiliki pasokan senjata. Jepang pernah mengalami penghentian impor bahan kimia, besi dan baja dari Jerman dan negaranegara Eropa lainnya sekitar 1914. Namun hal itu justru memicu pertumbuhan industri dalam negeri Jepang. Jepang mendirikan Nitrogen Research Institute untuk mendorong industri amonia. Selain itu, Jepang juga mendirikan departeman penelitian di Yawata Steel Mill dan membuat institut penelitian baja di Universitas Tohoku pada 1919. Lembaga ini terus berkembang menjadi Metal Research Institute pada 1922 setelah mendapatkan donasi dari perusahaan Sumitomo, Mitsubishi, dan perusahaan baja Kobe (Takenaga, 2000).

$\mathrm{Hal}$ ini menunjukkan kerjasama yang baik antara pemerintah, perguruan tinggi, dan industri. Adapun kontribusi perusahaan swasta adalah memberikan subsidi kepada universitas untuk mengembangkan riset dan penelitian terkait produksinya. Pada 1915 dibentuklah Rikagaku Kenkyushi (Riken) yaitu lembaga penelitian fisika dan kimia (Hiroshige, 1973). Pada 1917, lembaga ini digunakan untuk meningkatkan penemuan ilmiah dan pengembangan industri sebagai landasan terwujudnya kesejahteraan dan kekuatan negara.

Dalam teori ekonomi pertahanan, beragam isu pertahanan negara harus dapat ditinjau dari perspektif yang lebih luas. Ekonomi bidang pertahanan harus memiliki keahlian dalam menghubungkan metode ekonomi terhadap isu dan kebijakan pertahanan dalam teori dan empiris dengan mempertimbangkan berbagai lembagalembaga terkait dengan pertahanan (Yusgiantoro, 2014). Ekonomi pertahanan adalah ilmu pengetahuan guna mencari cara terbaik dari alokasi berbagai sumber daya nasional untuk memenuhi kebutuhan akan rasa aman dari ancaman (Yusgiantoro, 2014). Sebuah negara dengan sumber alam yang kaya dan posisi geografis yang penting untuk perdagangan laut secara politik dan militer tidak aman karena akan merangsang kecemburuan dari negara-negara yang lebih kuat untuk melakukan intervensi guna memperoleh keuntungan ekonomi (Mahan, 1991).

Manfaat yang dapat dipetik dengan pembangunan industri pertahanan adalah keleluasaan dalam memproduksi sendiri peralatan militer sesuai dengan kebutuhan, kemampuan, kondisi wilayah, dan karakter ancaman yang diprediksi mengancam kedaulatan negara tersebut. Negara yang memiliki industri pertahanan tentu tidak perlu susah payah membeli peralatan militer dari negara lain, yang prosesnya berlangsung lama, harganya mahal, dan sering kali dikaitkan dengan syarat politis tertentu. Biaya tinggi, ketidaksesuaian teknologi impor dan kurangnya kemampuan untuk memanfaatkannya secara efektif sebagian besar dikaitkan dengan 'mekanisme' transfer teknologi. Perusahaan yang memasok teknologi mengendalikan proses transfer untuk alasan kepentingan komersial mereka sendiri. Hal itu menyiratkan bahwa perubahan teknologi juga 'terlokalisasi' (Atkinson \& Stiglitz 1969) dan sering kali bersifat minor dan inkremental. Namun demikian, perubahan tersebut tidak kalah pentingnya secara ekonomi, karena jenis perubahan teknologi inilah yang 'menyempurnakan' inovasi besar, menjadikannya lebih kompetitif, atau membuat teknologi tertentu beradaptasi dengan lingkungan sumber daya yang berbeda. Rosenberg \& Nathan (1982) menyatakan bahwa proses inovasi teknologi itu sendiri terdiri atas perbaikan dan modifikasi kecil yang tidak terhitung banyaknya dan efek kumulatifnya penting. Sejak 1904, Jepang telah mengembangkan berbagai teknologi mandiri khususnya teknologi perkapalan yang dikembangkan oleh Mitsubishi Naval Yard.

Jepang merekontruksi industri pertahanannya melalui kerjasama keamanan Internasional yang menganut tiga prinsip yang diperbaharui dari pedoman buku pertahanan Jepang yaitu; (a). Clarification of cases where transfers are prohibited; (b). limitation to cases where transfers may be permitted as well as strict examination and information disclosure; (c). Ensuring appropriate control regarding extrapurpose use or transfer to third parties (Sato, 2015). Prinsip tersebut menekankan pentingnya keterlibatan pemerintah dalam pemeriksaan dan pemantauan. Prinsip baru tersebut menguraikan proses pemeriksaan dan persetujuan transfer alutsista dari Kementerian Ekonomi, Perdagangan dan Industri serta Kementerian Pertahanan; peran otoritas perizinan; mekanisme konsultasi tingkat menteri; dan peran dari Dewan Keamanan 
Nasional yang baru dibentuk dalam membuat keputusan akhir. Meski tidak semua keputusan dibuat di tingkat dewan keamanan, namun kasuskasus terkait alutsista akan berada di bawah pengawasan publik sehingga dapat memenuhi syarat transparansi sesuai prinsip-prinsip baru tersebut. Belajar dari hal tersebut, bahwa sinergi antar Lembaga dalam pembangunan industri pertahanan sangat diperlukan dalam rangka membangun kekuatan militer negara (Karim, 2014).

Dari uraian mengenai strategi pemimpin Jepang pada Perang Tsushima sudah semestinya Indonesia memetik banyak pelajaran. Hal itu terutama berkaitan erat dengan konsekuensi logis Indonesia sebagai negara maritim. Secara geografis, Indonesia memiliki modal sangat besar yang berpengaruh dan dipengaruhi oleh realitas geostrategis dan geoekonomi di wilayah Samudera Hindia dan Pasifik. Sementara secara historis, Indonesia memiliki potensi geopolitik dan budaya. Indonesia semestinya dapat berkontribusi positif bagi keamanan dan perdamaian kawasan sesuai kepentingan nasional (Putri, Octavian, \& Aritonang, 2018, pp. 1-15). Dalam konteks itu, Indonesia tentu harus membangun kekuatan maritim dengan mengintegrasikan kebijakan dari berbagai lembaga, baik pemerintah maupun swasta.

Perang Tsushima menjadi pembelajaran untuk pembangunan kemandirian industri pertahanan Indonesia, strategi penerapan yang dilakukan dengan membuat prioritas pembangunan produk militer Indonesia. Industri pertahanan merupakan industri negara yang dapat berbentuk Badan Usaha Milik Negara (BUMN) dan badan usaha miliki swasta yang secara terintegrasi menghasilkan alat pertahanan. Kelompok usaha itu terdiri atas land system (matra darat), naval system (matra laut), aerospace (matra Udara), dan security (keamanan dan kepolisian). Selain itu pembangunan alat utama sistem persenjataan (alutsista) Indonesia didasarkan pada masterplan pembangunan industri pertahanan dengan tahapan program-program sebagai berikut: (a) penetapan program, stabilisasi dan optimalisasi industri pertahanan, persiapan regulasi, serta persiapan new future products; (b) peningkatan kemampuan kerja sama produksi, serta pembangunan produk baru; (c) postur ideal dalam pembangunan industri (produk jangka menengah), peningkatan kerja sama internasional; (d) Program KKIP yang terdiri atas kemandirian industri pertahanan, kemampuan berkolaborasi secara internasional, serta pengembangan yag berkelanjutan.

Program pembangunan industri pertahanan juga memprioritaskan keunggulan produk yang dibangun yaitu tertuang dalam tujuh produk prioritas pengembaangan yaitu; propelan, roket, rudal, medium tank, radar, kapal selam dan pesawat tempur. Tiga dari tujuh produk prioritas nasional itu telah mencapai hasil yang dapat diproduksi dalam negeri yaitu Medium Tank Harimau, Kapal Selam dan Roket RHan-122B. (Alfiani, 2021). Pembangunan industri pertahanan juga menerapkan prioritas anggaran melalui pelaksanaan program-program seperti: (a) Program Pelaksanaan Tugas TNI; (b) Program Modernisasi Alutsista, Non Alutsista, dan Sarana dan Prasarana Pertahanan; (c) Program Pembinaan Sumber Daya Pertahanan; (d) Program Profesionalisme dan Kesejahteraan Prajurit; (e) Program Kebijakan dan Regulasi Pertahanan; (f) Program Riset, Industri, dan Pendidikan Tinggi Pertahanan; dan (g) Program Dukungan Manajemen.

\section{Simpulan}

Studi pertempuran laut pada perang Tsushima membuktikan sejarah panjang bagi Jepang dalam menciptakan kekuatan militer laut yang tangguh, terbukti dari penggunaan teknologi kapal yang cepat, penggunaan torpedo dan alat komunikasi telegraf. Kemenangan Jepang mempengaruhi kebangkitan industri pertahanannya. Upaya untuk membangun keunggulan SDM, pengembangan riset dan penelitian serta sinergi antara pemerintah industri dan akademisi terus dilakukan sehingga menghasilkan berbagai keunggulan dalam teknologi sampai dengan sekarang.

\section{Referensi}

Alfiani, L. S. (2021). Trends and Developments in Indonesia's Contemporary Foreign Military- 
Technical Cooperation. PhD Dissertation at Saint Petersburg State University.

Arrow, K. (1962). The economic implications of learning by Doing. Review of Economic Studies, June.

Atkinson, A. B., \& Stiglitz, J. E. (1969). A new view of technological change. The Economic Journal, 79(315), 573-578.

Bitzinger, R., \& Boutin, J. D. K. (2009). China's defence industries: Change and continuity. In Rising China: Power and reassurance.

Dore, R. (1984). Technological self-reliance: study ideal or self-serving rhetoric. In Technological capability in the third world (pp. 65-80). Palgrave Macmillan, London.

Elliot, A. \& Milne, D. (2019). War, tourism, and modern Japan. Japan Review 33, 2-28. https://www.jstor.org/stable/10.2307/266 52974

Fukasaku, Y. (2020). Technology and industrial development: An introduction. In Technology and industrial growth in PreWar Japan (pp. 21-34). Routledge.

Gordon, A. (2003). In the Modern History of Japan: From Tokugawa Times to the Present. New York: Oxford University Press.

Grove, E. (1998). Big fleet actions Tsushima, Jutland, Philippine Sea. Leicester: Brockhampton Press.

Hiroshige, T. (1973). Kagaku no shakaishi: Kindai nihon no kagaku taisei. Tokyo: $\mathrm{Chu}^{-} \mathrm{o} \mathrm{K}^{-}$ oron Sha.

Holmes, J. (2014). Strategic features of the South Tiongkok Sea: A tough neighborhood for hegemons. Naval War College Review, $67(2)$.

Ike, N. (1948). Western influence on the Meiji Restoration. Pasific Historical Review 17(1), 1-10.

Ikegami, E. (1995). Citizenship and national identity in early Meiji Japan 1868-1889: A comparative assessment. International Review of Social History 40(3): 185-221.

Ivanov, E., \& Karachtchouk, A. (2004). The RussoJapanese 904-05 (men-atarms). Oxford: Osprey Publising.

Karim, S. (2014). M. K. I. (2014). Membangun Kemandirian Industri Pertahanan
Indonesia. Jakarta: PT Gramedia Pustaka Utama.

Kowner, R. (2006). Between a colonial clash and World War zero: The impact of the RussoJapanese War in a global perspective. In The Impact of the Russo-Japanese War (pp. 2146). Routledge.

Lall, S. (1980). Monopolistic advantages and foreign involvement by US manufacturing industry. In The Multinational Corporation (pp. 3-28). Palgrave Macmillan, London.

Lardas, M. (1980). Tsushima 1905 death of a Russian fleet. Russian History, 7(1-2), 201212.

Lardas, M. (1980). Tsushima 1905 Death of a Russian Fleet. Russian History, 7(1-2), 201-212.

Lone, S. (1994). Japan's First Modern War Army and Society in the Conflict with China. Palgrave Macmillan Ltd.

Mahan, A. (1991). The Influence of Sea Power Upon History 1660-1783. Annapolis: Naval Institute Press.

Moleong, L. (2010). Metodologi Penelitian Kualitatif. Bandung: PT. Remaja Rosdakarya.

Pavitt, K. (1985). Patent statistics as indicators of innovative activities: possibilities and problems. Scientometrics, 7(1-2), 77-99.

Putri, S. R. K., Amarulla, O., \& Sovian, A. (2018). Implementasi kebijakan Indonesia sebagai Poros Maritim Dunia dalam perspektif manajemen pertahanan. Manajemen Pertahanan 4(1), 1-15.

Rosenberg, N., \& Nathan, R. (1982). Inside the black box: Technology and economics. Cambridge: University Press.

Sato, H. (2015). Japan's Arms Export and Defense Production Policy. In Center for strategic and international studies.

Stille, M. (2015). The Imperial Japanese navy of The Russo-Japanese War. Oxford: Osprey New Vanguard.

Takenaga, S. (2000). Ricardo and the history of Japanese economic thought a selection of Ricardo studies in Japan during the Interwar Period. Routledge Studies in the History of Economic. 
Till, G. (2006). Tsushima and Japan. The RUSI Journal, 151(3), 68-73.

Tuwanto, P. (2015). Politik pembangunan industri pertahanan nasional di era global. Gema Keadilan, 2(1), 36-45.

Yamamura, K. (1977). Success illgotten? The role of Meiji militarism in Japan's technological progress. The Journal of Economic History 37(1), 113-135.

Yusgiantoro, P. (2014). Ekonomi pertahanan. Jakarta: PT Gramedia Pustaka Utama. 